\title{
DESCARTES, ARCESILAU E A ESTRUTURA DA EPOKHÉ*
}

\author{
Thomas M. Lennon**
}

\section{RESUMO}

O ceticismo tem sido, nos últimos cinquenta anos, uma das principais lentes através das quais foi lido o papel filosófico de Descartes. Não apareceu ainda, todavia, uma identificação precisa do tipo de ceticismo que seja o mais adequado para essa leitura. Defendo a tese de que é especificamente o ceticismo acadêmico que caracteriza a metodologia de Descartes. $\mathrm{O}$ caso que serve para testar tal tese é a clássica noção de epokhé que surge em sua obra.

Palavras-chave: Descartes. Ceticismo pirrônico. Ceticismoacadêmico.Epokhé.

\begin{abstract}
For the past half-century, skepticism has been one of the principal optics through which Descartes.s philosophical role in the Great Century has been read. Sufficient precision has not appeared, however, in identifying the sort of skepticism that is most suited to this reading. My thesis is that it is specifically Academic skepticism that characterizes Descartes.s methodology. The test case is the classic notion of epoche as it emerges in his work.
\end{abstract}

Keywords: Descartes. Pyrrhonic skepticism. Academic skepticism. Epoché.

\footnotetext{
${ }^{*}$ Tradução de Bento Itamar Borges.

** Professor da University of Western Ontario. E-mail: tlennon@uwo.ca
} 
É comum pensarmos no Grande Século como o período que abarca a vida de Luis XIV (1638-1714); é a Era Clássica Francesa, cujo filósofo seria Malebranche, que nasceu no mesmo ano que o Rei Sol e morreu também no mesmo ano que ele. Se o Grande Século é o século XVII mesmo, deve ser entendido como uma era de ceticismo, delimitada pelas datas das mortes de Montaigne(1592) e de Bayle (1702), ou talvez, de forma mais estrita, pelas datas de publicação da obra de Charron, $D e$ la sagesse (1602), e da obra de Huet, de Censura philosophiae cartesianae (1689). O filósofo dessa era cética seria Descartes. É de uma importância óbvia, para compreendermos esse Grande Século, deixar claro até que ponto Descartes adere ao ceticismo.

Graças à obra de José Raimundo Maia Neto, podemos agora levantar essa questão de uma forma precisa, o que antes era impossível. Quando Popkin, pela primeira vez, chamou a atenção para o significado do ceticismo para a filosofia moderna em seus primórdios, ele tendia a se referir simplesmente ao ceticismo em termos gerais e a concentrar-se exclusivamente no ceticismo pirrônico. Maia Neto alertou-nos, entretanto, para importantes diferenças entre o ceticismo pirrônico e o ceticismo acadêmico.

Meu objetivo aqui é defender, ou pelo menos elucidar de alguma forma, minha concepção de Descartes como um cético acadêmico, emitida em meu recente livro, publicado pela editora Brill, The plain truth. E eu tentarei fazer isso, dirigindo-me a fontes antigas, com o foco no conceito de epokhé ou suspensão do juízo. O resultado pode ser uma lente para ler tanto Descartes quanto os antigos sob a estrutura da epokhé, para mostrar 1) que epokhé é, ou pode ser, uma estrutura lógica e não exatamente um estado psicológico, conforme querem os pirrônicos; 2) em que consiste essa estrutura; e 3) o papel que ela desempenha na metodologia do ceticismo acadêmico.

Vou começar tentando discutir essa visão de epokhé com a sugestão de que para o pirrônico, suspensão de juízo e tranquilidade são a mesma coisa; epokhé e ataraxia são idênticas (Maia Neto certa vez 
indicou que essa identidade pode ser encontrada em Montaigne; eu investigarei sua possível ocorrência em Sexto). Essa tese de identidade vai tanto sugerir como servir para realçar outra postulação de identidade, a saber, que para o acadêmico, suspensão é idêntica às considerações equipolentes que a efetivam enquanto sua causa formal; a epokhé é idêntica à isostenia. A relevância dessa postulação de identidade em relação a Descartes repousa na iteração da dúvida. A maneira-padrão de ler a dúvida cartesiana é que sua neutralização sistemática é definitiva, que um dos objetivos das Meditações é mostrar que, assim que se depara com os argumentos de Descartes, o desafio cético lançado a uma proposição não pode ser posto novamente. O que eu quero discutir é que assim que se compreende o papel da isostenia, a dúvida torna-se permanentemente iterável, e que o ceticismo acadêmico metodológico de Descartes consiste nessa iterabilidade da dúvida. Além disso, assim que se compreender a natureza, a estrutura e o papel da epokhé, será possível entender a razão para a atitude firmemente negativa de Descartes diante dos pirrônicos: eles violam o valor fundamental do ceticismo acadêmico, que veio a ser chamado integridade intelectual. Os pirrônicos não têm qualquer interesse pela verdade nem pela dialética que possa levá-los até ela. Vou começar com uma breve indicação da atitude de Descartes.

No Discurso do método, Descartes contrasta seu desenvolvimento da dúvida metódica com a prática do cético (pirrônico). 'Desenraizava, entrementes, do meu espírito todos os erros que até então nele se houvessem insinuado. Não que imitasse, para tanto, os céticos, que duvidam apenas por duvidar e afetam ser sempre irresolutos; pois, ao contrário, todo o meu intuito tendia tão-somente a alcançar uma certeza"1 Descartes não deixa claro o que poderia ser duvidar por duvidar, nem porque alguém

\footnotetext{
${ }^{1}$ AT VI, CSM I, 125. A referência usada para os textos de Descartes é a edição Adam et Tannery (Oeuvres de Descartes, publiées par Charles Adam et Paul Tannery, 11 volumes, Paris, Vrin, 1996). Na notação simplificada usada internacionalmente, AT indica a edição; os numerais romanos, o volume; e os algarismos arábicos, o número da página.
} 
se envolveria nisso e nem qual seria a objeção a agir dessa maneira, mas eis a versão reduzida da explicação que vou propor.

Horácio cunhou a famosa imagem pejorativa do epicurismo como filosofia de porcos. Mas ele poderia também ter feito o mesmo com o ceticismo (de Pirro), pois pode ser o caso de que os céticos não fossem menos comprometidos com o summum bonum mais apropriado à espécie suína que à humana (recorde-se da citação de Antigonus de Carystus, feita por Diógenes Laércio, sobre o modelo de ataraxia do sábio apresentado por Pirro a seus colegas passageiros: o porco, embarcado com eles, que continuava a comer durante uma tormenta). ${ }^{2}$ Há um texto de Aristocles, relatado por Eusébio, de acordo com o qual Enesidemo foi mais longe que Timon ao postular que o resultado da epokhé não era o calar-se e em seguida livrar-se das inquietações, mas o prazer. ${ }^{3}$ No mínimo, os seguidores zetéticos de Pirro não procuravam a verdade como a solução da epokhé, mas a epokhé mesma, uma vez descoberta como a ocasião da ataraxia, e, por conseguinte, um tipo de niilismo epistemológico. De fato, para o próprio Enesidemo, não poderia ter existido nenhum telos. De acordo com Fócio, o último de seus discursos pirrônicos foi "um ataque à finalidade, desautorizando a existência seja de felicidade, de prazer ou de prudência, ou de qualquer outro fim em que a persuasão filosófica pudesse acreditar, mas asseverando que o fim que todos eles celebram simplesmente não existe". ${ }^{4} \mathrm{O}$ desfecho deveria ser visto como um tipo mais geral de niilismo filosófico. Assim como Arcesilau, Pirro não escreveu

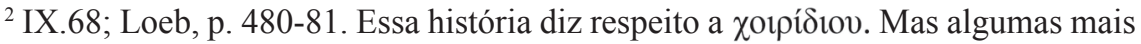
extensas estavam igualmente envolvidas. Antes, o relato traz Pirro que exibe sua

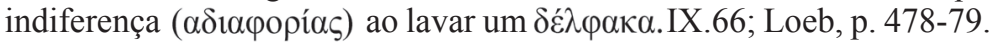

${ }^{3}$ Preparação para o Evangelho, 758 d. Não é dada nenhuma razão para a extensão. Mas há uma outra menção inconsequente de Enesidemo, como aquele que recentemente incitou o "absurdo" cético. 763d. Ver também LS p. 468, que sugere a felicidade como fim.
}

${ }^{4}$ LS, p. $483-84$. 
nada, mas ao contrário dele, Pirro não se envolveu em nenhuma dialética filosófica.

Uma complicação: naquilo que se tornou o locus classicus para a distinção entre ceticismo pirrônico e ceticismo acadêmico, Sexto nos desvia da distinção mesma. Nessa questão, Sexto nos conduz pelo caminho florido bem no início dos Esboços. Há três resultados possíveis para a busca de algo: sua descoberta (a posição do dogmático em relação à verdade), confissão do fracasso e sua indescobribilidade (a posição dos acadêmicos) e a continuação da busca (posição dos céticos). Mas o que é que os céticos procuram? A sintaxe do texto aponta apenas para a verdade. Mas que os céticos procurem a verdade é completamente incompatível com tudo que Sexto se põe a dizer sobre eles. Que os céticos não procurem a verdade, que eles almejem apenas a epokhé, eis uma alegação nada recente, que merece, contudo, uma nova ênfase, para entendermos certamente o desprezo que Descartes lhes devota.

Long e Sedley reconhecem que há ambiguidades em torno da exata maneira como a incognoscibilidade de todas as coisas se liga à suspensão do juízo. Mas, dizem eles, essas questões

não deviam permitir que se dissimule o caráter sumamente dialético do antigo ceticismo acadêmico. Esse é o aspecto que, acima de tudo, o conecta a sua herança platônica e que o separa do pirronismo. Onde o pirronismo nos adverte para nos mantermos afastados de todo emaranhado teórico por amor a nossa própria tranqüilidade, o ceticismo acadêmico primitivo prospera nas controvérsias teóricas; ele nos ensina a manter uma mente aberta sobre eles, por causa, não da tranqüilidade, mas, sim, da integridade intelectual. ${ }^{5}$

Para desenvolver esse tema, dirijo-me agora à primeira das postulações de identidade. Para Pirro, ataraxia e epokhé podem ser consideradas como realmente a mesma coisa, diferindo-se apenas

\footnotetext{
${ }^{5}$ LS, p. 447.
} 
conceitualmente, conforme Descartes diria. ${ }^{6}$ Os pirrônicos encontraram por acaso a tranquilidade, diz Sexto, quando, ao procurarem por ela na resolução de inconsistências preocupantes, viram que a resolução era impossível, e com isso acharam a tranquilidade ao suspenderem o juízo. Parece-me que a suspensão deveria ser a impossibilidade mesma e não mais um ato, baseado na impossibilidade percebida; com a tranquilidade deveria dar-se não algum estado a mais, conseguido com a suspensão, mas apenas a suspensão mesma. A tranquilidade reside na observada impossibilidade de jamais resolver-se a equipolência. A meta de Pirro é a tranquilidade e, uma vez obtida ao reconhecer-se a onipresente isostenia insolúvel, a dialética é silenciada, ou devia ser, exceto talvez como propaganda para manter ou propagar a epokhé.

A alegação de identidade está longe de ser óbvia e é, na verdade, passível de objeção. Recorde-se que Sexto introduz o relato da descoberta da ataraxia com a parábola de Apeles. Incapaz de retratar com espuma a boca espumante de um cavalo, Apeles ficou frustrado e atirou sua esponja, produzindo com isso o efeito exato que visava. Buscando a ataraxia através da resolução racional de inconsistências, os céticos a encontraram, "como que por acaso", ao reterem o juízo. ${ }^{7}$ Sexto ilustra com uma analogia a

\footnotetext{
${ }^{6}$ Essa tese foi primeiramente sugerida a mim pela apresentação oral de Maia Neto, Epoche as Perfection, na Biblioteca Clark em março de 2002. Veja p. 18, especialmente a nota 17. Algumas questões permanecem todavia em minha cabeça, sobre se Montaigne está falando de epoqué e ataraxia como ele entende tais conceitos ou como os pirronistas os entendiam, e, mais importante, se ele jamais afirmou realmente a tese da identidade. Há duas menções de ataraxia na "Apologie de Raimond”. Uma sugere a tese da identidade, mas de modo definitivo e apenas de passagem: "Os pirronistas dizem que o bem soberano é Ataraxia, que consiste em [qui est] uma imobilidade total do juízo..." Essays. p. 652; Oeuvres, p. 241. A outra menção nega com muita clareza a tese: $\mathrm{O}$ juízo do pirronista "confere seu acordo a nada. Isso conduz [les achemine à] a sua bem conhecida ataraxia: isto é, uma regra de vida calma e estável [condition de vie]...” Ibid p. 560; Oeuvres, p. 209. Pode-se ser conduzido apenas a algo diferente, que nesse caso é bem nitidamente um estado psicológico diferente.
}

${ }^{7}$ Outlines 1.12. 
relação entre epokhé e ataraxia. Uma está para a outra, como um objeto

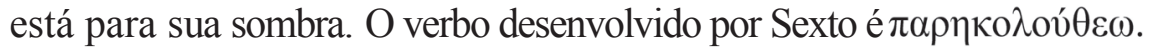
Thomas Stanley, em 1656, e mais recentemente, Annas e Barnes, Bury, Mates, todos o traduziram, de maneira bastante plausível, como "segue". 8 O sentido poderia bem ser que um segue o outro, como água fervente segue-se do ato de aquecê-la, isto é, a relação é causal. Em qualquer caso, os dois são realmente ou numericamente diferentes. Essa leitura é plausível porque a forma substantivada, $\alpha \kappa o ́ \lambda$ ov $\theta$ os, refere-se a um criado ou pajem de campanha, e ninguém atende ou segue a si mesmo, nesse sentido. Como dizemos hoje, a relação é irreflexiva.

Por outro lado, Etheridge aproxima-se daquilo que eu quero sugerir como uma possibilidade alternativa: os céticos "acharam que eram servidos pela tranquilidade mental tão seguramente quanto um corpo o é por sua sombra." Não por acaso, Sexto usa duas vezes o mesmo radical, sem o prefixo, no início do capítulo seguinte, nas figuras que resultam na epokhé. Ele ocorre primeiro como um verbo e depois como advérbio: "Já que estivemos dizendo que ataraxia segue-se da suspensão do juízo sobre tudo, consequentemente [ $\alpha \kappa o ́ \lambda$ ov $\theta$ ov ] a coisa seguinte seria explicar como atingimos essa suspensão." 10 A conexão entre epokhé e ataraxia é a mesma conexão que esta: já que p é o caso, segue-se que q é o caso. Ou seja, ataraxia segue-se logicamente, como deveríamos dizer, da epokhé. Literalmente, ataraxia é uma consequência de epokhé como a conclusão é uma conseqüência da premissa. Essa conexão íntima é anunciada pelo

\footnotetext{
${ }^{8}$ STANLEY, p. 477; ANNAS E BARNES, p. 11; BURY, p. XXX MATES, p. XXX. Groarke fala de um "pré-requisito". p. XXX

${ }^{9}$ ETHERIDGE, p. 42; (grifos do autor). Diógenes Laércio relata que a analogia é empregada pelos "seguidores de Timon e Enesidemo". LS p. 468. Depois, ao comentar a fórmula pirroniana para isostenia, Sexto tem de novo ocasião de indicar a natureza da relação entre epokhé e ataraxia. De acordo com Mates, a ataraxia "continua" a epoqué, p. 117; Etheridge, elas "vão de braços dados", p. 85; Bury fala de ataraxia como dependente de epoqué, p. 120-21. De acordo com Annas e Barnes, os pirronistas julgam que a tranquilidade intervém na epoqué, p. 52.
}

${ }^{10}$ Cito Mates, que gentilmente capta o que eu quero sugerir. p. 93. 
prefixo ao verbo na primeira ocorrência: $\pi \alpha \rho \eta$, deperto, ou intimamente. Mais ainda, o verbo tem um reconhecido sentido metafórico: obedecer. Geralmente, obediência é uma relação entre relata numericamente distintos. Mas no caso de relação lógica de implicação, obediência normativa, a relação só prevalece quando os relata são (de maneira relevante) os mesmos. (Isto é, p segue-se de p \& q, mas de maneira relevante apenas de p.) Na passagem imediatamente antes da parábola de Apeles, Sexto diz que aquele que não determina a bondade de nada, nada persegue, "portanto ele está em um estado tranqüilo" ( $\delta$ ió $\varepsilon \varepsilon \rho \alpha \tau \alpha \rho \alpha \kappa \tau \varepsilon i ́)$. Isso expressa de modo perfeitamente claro uma relação lógica. Seria natural, então, ler Sexto como quem diz que a ataraxia é eo ipso produzida pela epokhé. ${ }^{11}$ Portanto, a sombra de um objeto apenas é aquele objeto existente em um certo lugar, com uma única fonte de luz, diante de uma tela, e sem quaisquer objetos intervenientes.

Minha conclusão é que, considerando-se todas as coisas, o texto de Sexto é provavelmente sub-determinado, mas, pelo menos é isso. De fato, a indeterminação deve ter facilitado bem o desvio da ataraxia para o prazer e, por fim, para o niilismo de rejeitar qualquer telos. Eu devo sugerir mais adiante que Arcesilau visava preservar a pureza da epokhé ao insistir

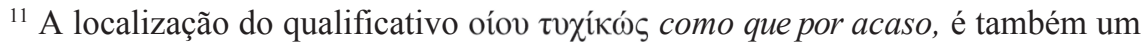
problema. Na tradução, ela cai dentro da oração principal ou da subordinada? $\mathrm{Ou}$ seja, é o descobrir ou o que é descoberto que ocorre por acaso? Se for o último, então é menos provável, embora não inconcebível, que ataraxia e epoqué sejam idênticos. De novo, há uma divergência de traduções; cf. Etheridge com Annas e Barnes. Consequentemente, por que a descoberta "como que ao acaso"? Uma resposta seria que qualquer outra coisa seria uma meta ensejada e conquistada, seria em muito como uma teoria sobre o real corroborada pela experiência. Mesmo o qualificativo "como se" afasta o cético de um apelo ao conceito minimamente objetivo de chance. Mas não está sendo afirmado o assunto do fato objetivo referente à conexão descoberta? Talvez não em um sentido que viola o pirronismo. A sentença declarativa deve ser entendida como uma estratégia retórica perfeitamente consistente com o compromisso da ataraxia em qualquer base, racional ou não. A alegação, portanto, deve ser tomada como uma instância de darwinismo literário: nenhuma opinião sem esse tipo de retratação teria tido a chance de ter sobrevivido para nosso consumo.
} 
sobre ela como uma noção lógica.

Por enquanto, pergunto: por que a isostenia universal? Por que a equipolência de uma visão qualquer com uma outra não se deve apenas a nossa própria estupidez ou falta de imaginação ao resolver o corte? Por que a busca por uma solução na verdade do tema não continua com o "zetético" nome de pirronismo? No texto de Aristocles que eu já citei, Timon é referido, de terceira-mão, ao dizer que

Pirro declarou que as coisas são igualmente indiferentes, imensuráveis e inarbitráveis. Por essa razão, nem nossas sensações, nem nossas opiniões nos dizem verdades ou falsidades. Por conseguinte, por essa razão, não deveríamos colocar nem um pouco de nossa confiança nelas, mas devíamos ser não-opiniosos, descomprometidos e inabaláveis ao dizermos a respeito de cada coisa individual que ela é não mais do que ela não é, ou que ela tanto é quanto não é, ou que ela nem é e nem deixa de ser. ${ }^{12}$

Portanto, do fato de que devíamos buscar a epokhé segue-se, direta ou indiretamente, de uma alegação ontológica sobre os referentes dos juízos em disputa. E é ainda uma alegação ontológica mesmo se devêssemos anexar a retratação sobre a qual Sexto insiste: "quando o cético diz 'todas as coisas são indeterminadas', ele toma a palavra 'são'. no sentido em que elas "aparecem a ele". Ou seja, fala-se de coisas não em si mesmas, mas como elas aparecem. Contudo, a alegação é que coisas parecem indeterminadas e, portanto, a isostenia não pode jamais ser eliminada.

Aristocles não diz nesse texto por que Pirro sustenta que as coisas são indiferentes, mas poder-se-ia pensar no sofista Górgias, que afirmava que nada existe, e que se qualquer coisa existisse de fato, não poderia ser conhecida, e mesmo que algo fosse conhecido, não se poderia falar sobre

${ }^{12}$ LS, p. $14-15$ 
isso. ${ }^{13}$ Poderíamos afirmar, ao dizer que não há nada para ser conhecido: niilismo ontológico, se me permitem. Segundo formulação de Long e Sedley, ou não há fatos, ou, se houver, eles não são os tipos de coisas que estejam, mesmo em princípio, disponíveis para a cognição. Em qualquer caso, é o tipo de visão que naturalmente sugere tanto desistir da busca da verdade quanto da satisfação, pois, afinal, a busca foi fútil.

Com Arcesilau, o quadro é muito diferente. A verdade poderia ser de difícil acesso, submergida em um abismo, conforme afirmou Demócrito, mas isso é uma forte razão para assegurar que a epokhé bloqueie o preconceito, a paixão, a presunção, a inferência precipitada, a autoridade inadequada e qualquer outra coisa que possa impedir a habilidade natural para conhecer a verdade. Se nós fracassarmos ao perceber a verdade, a culpa é nossa, não da verdade mesma. Mesmo que a verdade esteja simplesmente aí para ser vista, como é para Descartes, ainda se requisita a epokhé a fim de remover os obstáculos a sua percepção, que estão inteiramente conosco.

Não parece haver qualquer texto que identifique a ataraxia como uma preocupação de Arcesilau. Portanto, não há qualquer questão para ele sobre a identidade dela com a epokhé. Mas é plausível, como foi, ler sua epokhé como idêntica aos argumentos que a produzem enquanto sua

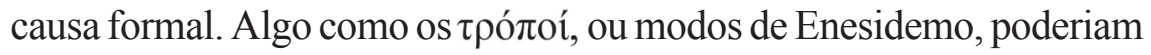
perfeitamente ter sido o meio pelo qual a equipolência foi visada por

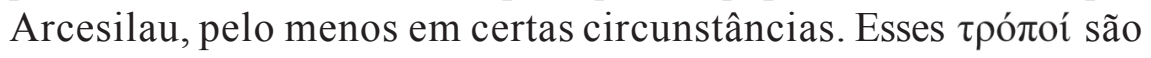
chamados por Sexto modos de epokhé, que eu entendo não como meios para a epokhé, mas como versões dela. ${ }^{14}$

Um aparente obstáculo para a identificação de epokhé com isostenia é que um é uma noção psicológica enquanto o outro é uma noção lógica (isso seria um obstáculo do ponto de vista de Casey Perrin, que

\footnotetext{
${ }^{13}$ Sexto, Against the logicans [Contra os lógicos], I, p. 65.

${ }^{14}$ Essa é a leitura de modo no século XVII: o modo [façon d'être] de uma coisa é apenas aquela coisa existindo de uma certa maneira.
} 
distingue entre razões para duvidar e razões para suspender o juízo). Essa disparidade é sublinhada pela identidade pirrônica de ataraxia e epoqué como noções psicológicas, especialmente quando ataraxia veio a ser entendida como prazer. Minha opinião que a epoqué acadêmica, e talvez a primeira epoqué pirrônica, deve ser lida metaforicamente como o bloqueio lógico do juízo, e não literalmente como o estado mental de suspensão que resulta de sua percepção. Isso é o "segurar a respiração de alguém" que pode traduzir ao pé da letra o verbo. Não é por acaso que o termo

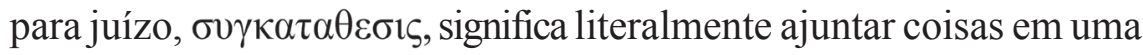
lista. Portanto, uma leitura metafórica de tais termos parece mais que justificada. Por que dar preferência à leitura metafórica? Imagine uma pílula que produz o estado mental de suspensão. Será que o pirrônico tomaria a pílula? Por certo, sim. E o acadêmico? Certamente, não a tomaria. Contudo, o vigoroso dialeto em que se engajou Arcesilau poderia ter sido poupado, e a epoqué poderia ser antes alcançada, apenas tirando-se uma soneca. A questão principal, em qualquer caso, é que Descartes não teria tomado uma pílula da certeza.

A epokhé interpretada como a equipolência de opiniões em disputa autoriza a operação daquilo que Descartes, no início do Discurso, chama juízo, ou a habilidade para distinguir o verdadeiro do falso. Se tudo que eu tenho é um argumento em favor de $p$, então fico inclinado a aceitar $\mathrm{p}$, mas sem ver que é verdadeiro. Para isso, eu preciso que a cogência do argumento a favor de $p$ seja contrabalanceada por um a favor de não-p. $\mathrm{O}$ ar de paradoxo, no caso, dissipa-se se os argumentos forem tomados como mera heurística. Um bom argumento não apenas apresenta a verdade, mas nos capacita a vê-la por nossa conta. Poder-se-ia pensar nos acadêmicos, por contraste com o formalismo do tipo leibniziano, por meio do qual a verdade é uma questão de provabilidade. Pense-se nos acadêmicos, em vez disso, como intuicionistas.

Em todo caso, a recomendação metodológica seria gerar continuamente a epokhé sob esse feitio, com opiniões opostas de igual cogência, até que não se possa mais fazê-lo, caso a aprovação não possa 
ser impedida. Essa é a recomendação explícita de Descartes, no Discurso com a primeira regra do método, e na Quarta Meditação com a doutrina da vontade coagida pela evidência. Atribuir a recomendação a Arcesilau é, com certeza, altamente especulativo, mas de fato fornece uma leitura não-dogmática do lema acadêmico do nada saber. Qualquer alegação desse tipo atribuída a um acadêmico pode ser entendida em dois sentidos. Primeiro, é uma rejeição de toda autoridade, inclusive a mais importante, a de cada um. Eu poderia conhecer algo, mas quando eu digo isso, mesmo para mim, eu removo todo novo discurso sobre aquele tópico; todo argumento e toda dialética cessam. Um segundo sentido, relacionado, é que a recusa em dizer "eu sei” é uma indicação de epokhé perpétua; isto é, uma abertura sem fim à revisão de todas as opiniões. Eu poderia perfeitamente manter muitas opiniões, mas eu nunca as expressarei exceto sob condições de equipolência, de modo a testá-las e talvez revisá-las ou rejeitá-las.

Essa interpretação de epokhé parece compatível com o testemunho de Cícero sobre Arcesilau, mas há algum testemunho aparentemente contrário de Sexto. Na passagem 1.33 dos Esboços, Sexto alega que Arcesilau compartilhava as opiniões de Pirro, de modo que "sua maneira de pensar é quase idêntica a nossa". Ele não faz nenhuma asserção sobre a realidade das coisas e suspende o juízo sobre todas as coisas. "Ele

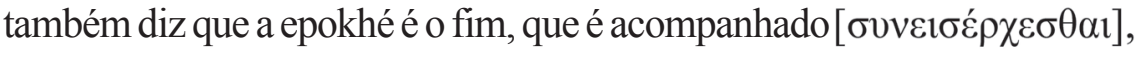
como dissemos, pela ataraxia." Isso parece contra-evidência para o contraste que eu estou delineando; mas talvez não seja.

Está claro que Sexto é o único a fazer a conexão entre ataraxia e epokhé. Epokhé, como dissemos, é seguida de ataraxia. Além disso, o fim sobre o qual ele fala poderia não ser o valor máximo ou a preocupação última para Arcesilau, mas apenas aquilo para o qual devemos mirar como algo que está dentro de nosso poder. A verdade poderia estar além de nós, apreendida, longe de nossos esforços para evitar o erro, apenas como se fosse por acaso, e portanto ela não pode ser um fim nesse sentido estrito. O fim último permanece a verdade. Em todo caso, Sexto está 
fundamentalmente preocupado, nesse texto, em traçar a distinção entre os pirrônicos e a Nova Academia de Carneades e Clitômaco, o que ele consegue ao distingui-los de Arcesilau. Portanto, esse texto não é tão preocupante para minha abordagem como poderia parecer à primeira vista.

Cícero é mais prontamente atraído por minha abordagem. Um dado fundamental na interpretação do ceticismo acadêmico é que Arcesilau envolveu os estóicos, e Zenon de modo específico. Em um texto crucial, Cícero explica porque Arcesilau agiu assim. Toda tradução é uma grande tarefa, no caso de Cícero, portanto vou dar apenas uma paráfrase. Arcesilau não criticou Zenon apenas por criticar, pelo contrário, ele o fez para descobrir a verdade. De sua recente doutrina, tanto fica claro que o sábio nunca expressa uma opinião sobre nada [nihil opinari] ${ }^{15}$ Aí, de um golpe, Cícero reverte completamente o significado costumeiro atribuído ao lema do nada saber. Ao formular a nova contribuição de Arcesilau, Cícero coloca com clareza sua meta epistêmica. Que ela não saiba nada não é a finalidade acadêmica, como Sexto pensava, mas um meio para (o conhecimento da) a verdade.

Mas como a epokhé serve de meio para a verdade? Há pelo menos dois sentidos. Um é imediatamente sugerido pelo texto de Cícero. O sábio não apenas pode suspender o juízo, mas é obrigado a agir assim. A única razão para essa necessidade de suspensão seria o fracasso em ver a verdade, o que vale dizer que a epokhé não é permanente e

\footnotetext{
15 "Que Arcesilau não travou batalha contra Zenon simplesmente visando criticá-lo, mas realmente desejava descobrir a verdade decorre do seguinte: que é possível a um ser humano não defender nenhuma opinião, e não apenas que é possível, mas que é o dever do homem sábio, não só nunca tinha sido distintamente formulado como nunca tinha sido posto por quaisquer de seus predecessores; mas Arcesilau julgou essa opinião tanto verdadeira quanto honrada e digna de um homem sábio." Academica 2. 77; Loeb p. 562-65. Ver também Santo Agostinho, Contra Academicos 2.11: "A doutrina dos acadêmicos era que o homem não pode obter conhecimento ... e que, contudo, um homem pode ser sábio, e que toda a função de um homem sábio... é exibida na peleja pela verdade.” 2. 11; LS p. 442.
} 
estabelecida em princípio, mas temporária e contingente sobre a falta de percepção da verdade. Suspender o juízo até que não se possa mais suspendê-lo seria o desfecho metodológico.

Em segundo lugar, o texto continua imediatamente a imaginar uma permuta prolongada entre Arcesilau e Zenon através do critério estóico da impressão cognitiva. Arcesilau atacou de maneira notável essa impressão que deve vir do que é, representado como ele é, e de nada mais. Ou seja, o objeto de uma impressão cognitiva deve ser real e representativo, e deve ser de tal modo a ocorrer somente se essas duas condições forem encontradas. Arcesilau argumentou que a condição externalista (que a impressão vem apenas do objeto que ela representa) nunca é satisfeita, que é sempre possível que a impressão seja falsa, já que ela pode vir de outra coisa. Cícero diz, na verdade, que esse ponto, mais que suspensão de juízo, é o que continuou em discussão até sua própria época. Mas, no que diz respeito aos estóicos, a suspensão, entretanto, leva ao malogro de seu próprio critério ser sempre satisfeito. Os estóicos estariam implicados justamente porque seu critério nunca é satisfeito. Portanto, minha tendência é ler o texto como inteiramente ad hominem da parte de Arcesilau, uma leitura de algum modo sugerida pela forma dialógica em que é apresentada.

Para trazer em outras palavras o argumento ad hominem, Arcesilau está para os estóicos como Descartes está para si mesmo na primeira Meditação. Charles Larmore vislumbra o 'eu' da primeira Meditação como um veículo para um diálogo entre um aristotélico e um cético, em que são expressas outras opiniões além das de Descartes. Eu não tenho sido capaz de aceitar essa opinião, e, em vez disso, insisti que o referente de primeira pessoa, pronome singular, o assim chamado meditador, é apenas o próprio Descartes a expressar tão somente suas próprias opiniões. ${ }^{16}$ Mas eu agora vejo que a estrutura dialógica revela algo essencial sobre o método da dúvida, que atua com base em uma série de desafios. É irrelevante para o método se sou eu desafiando a mim

${ }^{16}$ Para as razões veja meu The plain truth, p. 210ss. 
mesmo ou se levo você a desafiar a si mesmo, pois o método em ambos os casos repousa na integridade intelectual. Equipolência e epokhé barram o preconceito e o resto dos obstáculos a nossa apreensão da verdade. A prova decisiva contra a leitura dogmática negativa de Arcesilau é o Urtexto [texto primordial] para a concepção de integridade intelectual. Nós, acadêmicos, diferimos dos dogmáticos, diz Cícero, apenas em "sermos mais livres e desembaraçados ao dispormos de nossa plena capacidade de julgar [integra... iudicandi potestas], e por não nos submetermos a nenhuma compulsão de apoiar dogmas baixados quase como decretos por certos mestres".

Por outro lado, o zelo acadêmico pela investigação [studium exquirendi] não é menor que aquele dos dogmáticos; "o único objeto [dos acadêmicos] é, ao argumentar em ambos os lados, [chegar até] a verdade ou a aproximação mais vizinha da verdade". ${ }^{17}$ Em outras palavras, o lema acadêmico é apenas uma expressão da integridade intelectual.

Recorde-se que Aristocles relatou que a ataraxia pirrônica degenerou em prazer. No mesmo texto, Aristocles segue criticando o pirronismo, em termos completamente vulgares. Por exemplo, ele pergunta, ao tentar provar a incerteza de todas as coisas, se o pirrônico fala com conhecimento ou não. Se não, não há razão para acreditar nele; se for o caso, então ele refuta a si mesmo. ${ }^{18}$ Ora, os pirrônicos deram uma resposta a esse linha de refutação: seus argumentos são como certas catarses, que se purgam juntamente com os excrementos que elas estão encarregadas de remover. Sem muita eficácia, Aristocles afronta essa refutação como "idiota", reduzindo o discurso dos pirrônicos a disparates. Todavia, em seguida, ele diz algo de interesse: "no caso da verdade, não há similaridade entre o purgante e o argumento deles [dos pirrônicos]. Pois a droga é eliminada e não permanece no organismo; o argumento, no entanto, deve ficar nas almas dos homens, conservando-se sempre o mesmo e

\footnotetext{
${ }^{17}$ Academica 2. 7-8; Loeb, p. 472-75.

${ }^{18}$ EUSÉBIO, 760b-d.
} 
conquistando sua crença, pois ele é a única coisa que os torna incapazes de duvidar." 19 Descartes tem também argumentos (ou pelo menos percepções putativamente claras e distintas) armazenados em sua alma. E enquanto estão lá eles podem ser requisitados a fim de superar certas dúvidas. Mas eles estão sempre abertos à rejeição, mesmo que, enquanto ele estiver ciente deles, não se possa imaginar como poderia acontecer tal rejeição. O ceticismo acadêmico de Descartes consiste na possibilidade dessa rejeição. Mas, vamos primeiramente à interpretação standard, que todos nós tomamos junto com o leite de nossas mães. Estou certo de que eu o tomei.

Durante os últimos cinquenta anos, tem havido um acordo quase universal sobre o que Descartes considerou ser o significado do cerne de sua filosofia. A primeira parte dessa interpretação standard dá por estabelecido que, à época de Descartes, o ceticismo, que tinha ficado em um período de dormência de mais de um milênio, poderia ser encontrado em todos os lugares, por diversas razões. Descartes via como projeto de sua filosofia a refutação desse ceticismo que recrudescia, o que ele visava aplicando o ceticismo contra si mesmo. Ou seja, ao seguir a recomendação dos céticos de duvidar de tudo o que pudesse ser duvidado, Descartes almejava mostrar que havia algo de que não podia duvidar, que era, portanto, certo e podia ser conhecido, e que, por uma cadeia de raciocínio aceitável, um mundo inteiro de conhecimento estava disponível. O resumo é conhecido: a dúvida radical é encerrada com o cogito, que conduz à clareza e à distinção como critérios confiáveis do conhecimento, que capacita conhecer Deus e, com isso, o resto do mundo.

Na segunda parte da interpretação standard consta que fracassa a tentativa de Descartes em refutar o ceticismo. De maneira típica, vê-se o erro ocorrer quando Descartes se move além do conhecimento de sua própria existência demonstrada no cogito.

Embora pudesse ser o caso de que, mesmo para ser iludido, eu

\footnotetext{
${ }^{19}$ EUSÉBIO, $762 \mathrm{~b}$.
} 
deva existir, não se segue que minha certeza seja uma função da clareza e distinção de minha percepção de que eu existo. Por tudo que sei, deve ser porque eu estou tendo uma percepção na terça-feira é que ela é correta. Portanto, para fechar a lacuna entre a verdade e seu critério, Descartes se volta para uma prova da existência de Deus, que não permitiria qualquer clivagem desse tipo. Mas, ao armar essa prova, Descartes confia em premissas que são aceitas com base precisamente no critério cuja confiabilidade ele está tentando estabelecer. Seu argumento fracassa por ser circular, e assim Descartes é, segundo Popkin, um cético malgré lui.

Essa interpretação standard enfrenta inúmeros inconvenientes. $\mathrm{O}$ termo "ceticismo" e seus cognatos não aparecem em nenhum lugar nas Meditações, texto em que se baseia inicialmente. Há pouquíssimas referências espontâneas ao ceticismo em outras passagens do corpus cartesiano, e em que aparece, é apenas incidentalmente, en passant. Quando os céticos de fato conseguem uma aparição, eles, tipicamente, são apresentados por seus críticos, não por Descartes. O ceticismo, ou seja, o ceticismo pirrônico, não tem qualquer interesse para Descartes; $a$ fortiori, não é um objeto de refutação. O texto do Discurso que eu li no início, no qual Descartes contrasta a si diante dos céticos (pirrônicos), é uma exceção nesse aspecto, mas não o desdém que ele expressa lá. A atitude de Descartes em relação a eles é sempre de desprezo.

O desprezo pelos pirrônicos não implica, todavia, em adesão aos acadêmicos. Portanto, vamos voltar a Cícero e para a sequência de seu texto na qual a epokhé de Arcesilau é caracterizada como direcionada para a verdade. Aí Cícero introduz a questão da phantasia kataleptike, a impressão cognitiva que era o critério estóico, que, diz ele, é a questão permanente entre os estóicos e seus críticos acadêmicos, que sobrepuja até mesmo o tema da epokhé. ${ }^{20}$ Como vimos, Arcesilau atacou essa impressão com base em que nenhuma impressão advinda do verdadeiro poderia ser de tal modo que ela não pudesse também vir do falso. Em

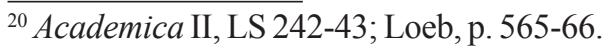


resumo, a impressão cataléptica é em si mesma indiscernível, indistinguível de uma impressão falsa, e por essa razão todas as coisas são incognoscíveis. Como estratégia cética, esse argumento antecipa rigorosamente o procedimento de Descartes nas Meditações. O problema que esse argumento levanta para minha interpretação das Meditações é que, nas mãos de Arcesilau, ele foi apontado contra uma noção exatamente do tipo que Descartes estava interessado em defender, a saber, a percepção clara e distinta. Assim como a impressão cognitiva dos estóicos, a percepção clara e distinta de Descartes era cataléptica, “capaz de ser agarrada", em dois sentidos. Primeiro, a impressão agarra um objeto; recorde-se a imagem de um punho em Zenon, que com seu polegar prensador pode segurar algo além de si mesmo. Segundo, a impressão nos agarra; no palavreado estóico, "alguém é apanhado pelos cabelos" e obrigado a aceitar a impressão. Essas são percepções claras e distintas essencialmente cartesianas. Além disso, há o conceito estóico de episteme, traduzido como conhecimento científico, ilustrado por Zenon como um punho agarrado pela outra mão. De acordo com Stobeu e outros autores, inclusive Sexto, essa episteme é tida como invencível mesmo diante do desafio da razão. Eis uma percepção clara e distinta assegurada pela eliminação da dúvida hiperbólica. Finalmente, com base em suas percepções claras e distintas, Descartes emite asserções e o faz com uma feição que parece ser dogmática, autoritária. De fato, ele não consegue ver como suas asserções poderiam, talvez, ser falsas. Como, então, pode Descartes ser um cético acadêmico metodológico? Vamos voltar agora para as Meditações e para uma questão sobre a dúvida, que está intimamente ligada à epokhé.

Com que frequência deve alguém duvidar e estar aberto à dúvida? É uma pergunta normativa, intimamente ligada à epokhé, na medida em que alguém é responsável por aquilo em que acredita. A integridade intelectual do cético acadêmico requer que ele assuma responsabilidade por todas suas convicções, sempre. Ou seja, suas crenças estão sempre abertas à revisão. Nenhum compromisso epistêmico é jamais definitivo. 
Ora, Descartes parece obviamente correr no sentido contrário de tal atitude com sua doutrina das percepções claras e distintas, que são, per force, aceitas como verdadeiras. Mais ainda, ele diz no início das Meditações em um texto que introduz a metáfora das fundações, que por causa de sua aceitação prévia da falsidade como verdade, "foi necessário, uma vez no curso de minha vida [semel in vita], demolir tudo por completo e começar de novo a partir das fundações, se eu quisesse estabelecer qualquer coisa nas ciências que fosse estável e apta a durar.."21

É absolutamente necessário que todos duvidem, como ele fez, exatamente uma veza fim de ter algum conhecimento. Para dramatizar um pouco, Descartes acredita que ele é o primeiro desde sempre a ter conhecimento genuíno no sentido de dispor de uma certeza inabalável sobre aquilo em que acredita. Nas Segundas objeções, Mersenne atribuiu a ele como uma reductio planejada o fato de que se é necessário o conhecimento da existência de Deus, do jeito que Descartes postula, então os antigos geômetras ateus não tinham tal conhecimento. Descartes aceita a inferência. Embora esses geômetras pudessem estar certos de suas crenças - de fato, se eles tinham percepções claras e distintas sobre o que eles acreditavam, então eles deviam ter tido certeza - eles não tinham, não obstante, certeza inabalável por não estarem em condições de refutar o cético que levanta a dúvida hiperbólica de que nossas percepções claras e distintas são falsas.

Eis finalmente o ponto que eu quero marcar sobre a compatibilidade entre a opinião de Descartes recém-descrita e a epokhé acadêmica. Descartes diz que se eu quero a certeza, devo duvidar uma vez. Mas, eu

\footnotetext{
${ }^{21}$ AT VII, 17; CSM II, 17. Do ponto de vista de seu magistral livro Skepsis (Ceticismo), Gianni Paganini insiste que céticos tais como La Mothe Le Vayer continuam sendo objeto da preocupação cartesiana na medida em que a existência de Deus e a imortalidade da alma precisam de defesa contra as ameaças deles. Veja essa resenha de The Plain Truth. Meu artigo é pelo menos uma resposta parcial a ele ao tentar dar uma base para a desobediência repudiável que eu percebo em sua atitude diante deles.
} 
quero acrescentar, que a fim de manter a certeza, eu devo estar sempre aberto à dúvida, pelo menos para duvidar "com base em razões poderosas e bem-pensadas". É absolutamente necessário duvidar uma vez para obter a certeza, mas a depender do que o cético seja capaz de apresentar, ou, mais precisamente, do que eu seja capaz de inventar, tudo está sempre epistemologicamente disponível. Ora, Descartes certamente pensa, de fato postula perceber clara e distintamente, que com a dúvida hiperbólica ele inventou as mais poderosas e bem pensadas razões concebíveis para abalar sua certeza, e que ele superou essas dúvidas. Mas a possibilidade de erro, embora para ele inconcebível, permanece não obstante. Pensa que ele tem certeza permanente, mas poderia estar enganado.

Na Terceira Meditação, Descartes reconhece explicitamente a possibilidade de erro, de acordo com o cogito e com a regra da verdade que se deriva dele. $\mathrm{O}$ demônio mau foi eliminado por ele e, ao examinar como conseguiu isso, encontra uma regra para apreciar todas as outras verdades: ele pode estar certo sobre o que ele percebe clara e distintamente como verdadeiro. Mas, em lugar de dirigir-se para uma prova do mundo externo, ele recua: "embora eu aceitasse previamente como totalmente certas e evidentes muitas coisas que depois eu percebi que eram duvidosas." O termo aqui traduzido como "embora" é tamenverum: não obstante ou apesar de. Apesar do cogito e da regra da verdade, eu poderia ainda aceitar como totalmente certas e evidentes coisas que se revelarão duvidosas. De fato, elas poderiam até ser falsas, como ele admite bem mais tarde, perto do final da Quinta Meditação: “...tem havido casos freqüentes em que eu considerei coisas como verdadeiras e certas, mas fui levado mais tarde por outros argumentos a julgá-las como falsas". E por causa desse fato admitido de erros sobre percepções claras e distintas, permanece a possibilidade de que é ilusão tudo daquilo que ele toma como percepção clara e distinta da verdade. Na Terceira Meditação, ele volta, por conseguinte, a se esforçar por banir essa possibilidade com a prova da existência de Deus. O desfecho é que todo conhecimento, sem excetuar o cogito, depende da existência de Deus. Isso é o que ele 
diz ao concluir a longa prova da existência de Deus, na Quinta Meditação. Vale a pena citar a passagem na íntegra:

Pois, ainda que eu seja de tal natureza que, tão logo compreenda algo bastante clara e distintamente, sou naturalmente levado a acreditá-lo verdadeiro; no entanto, já que sou também de tal natureza que não posso manter sempre o espírito ligado a uma mesma coisa, e que amiúde me recordo de ter julgado uma coisa verdadeira, quando deixo de considerar as razões que me obrigaram a julgá-la dessa maneira, pode acontecer que nesse ínterim outras razões se me apresentem, as quais me fariam facilmente mudar de opinião se eu ignorasse que há um Deus. E assim eu jamais teria uma ciência verdadeira e certa de qualquer coisa que seja, mas somente opiniões vagas e inconstantes. ${ }^{22}$

Como poderia Descartes admitir a possibilidade de estar errado se o erro é inconcebível? Como poderia ser falso o cogito, a postulação "eu sou, eu existo"? No fim das contas, por causa de uma clivagem entre a assertibilidade com garantia última e a verdade absoluta. Quando tudo está epistemologicamente dito e feito, quando toda a evidência chegou, e todos os argumentos foram aprontados, e a verdade, no sentido de Peirce, tiver sido encontrada, ainda aí podemos estar enganados. No segundo conjunto das Objeções, Descartes concede que poderíamos estar firmemente convencidos da verdade de algo que pode parecer falso a Deus ou a um anjo, portanto isso, para falar "de modo absoluto", é falso. ${ }^{23}$ Admitir essa clivagem, esse falibilismo quiçá inesperado, é exatamente o que seria esperado da modéstia acadêmica. Basear o ceticismo na clivagem, contudo, rejeitar o que é percebido clara e distintamente como verdadeiro, seria (se fosse possível fazer assim) gratuito. Não há razão para afirmar que a clivagem de fato prevalece, e temos toda razão para afirmar que

\footnotetext{
${ }^{22}$ CSM II, 48.

${ }^{23}$ CSM II, 103
} 
não. O cético não é razoável, voluntariosamente assim, pois a dúvida é inteiramente um ato da vontade, o pecado de Satã, na verdade, e por conseguinte o cético está além do desprezo. Novamente, o cético (pirrônico) duvida apenas por duvidar.

Descartes, em contrapartida, duvida apenas por boas razões, as quais, quando ganham a disputa, o deixam com a certeza em relação à verdade. Ele pensa que sua certeza é permanente, porque ele superou o que considera ser a razão mais forte possível para a dúvida. Mas pode estar enganado quanto a isso. Algum novo ateu poderia vir e apresentar um desafio até então nunca imaginado, e a menos que Descartes fique aberto a encarar esse desafio, sua presente certeza não é nada mais que preconceito dogmático. Em outras palavras, tudo o que Descartes afirma carrega um operador implícito: videtur, parece-me que. Não por estar ele sem certeza (eis a base pirrônica para o operador), mas porque ele não reclama infalibilidade, e essa é a linha-mestra do ceticismo acadêmico metodológico de Descartes.

Vou terminar com três comentários rápidos. Primeiro, essa possibilidade de erro não deve ser confundida com o infame círculo que tem sido uma objeção corrente contra Descartes ab initio. O texto, na verdade, apenas notou pontos para a resposta definitiva à objeção. Se alguém tem dúvidas sobre a confiabilidade de sua clara e distinta percepção, este precisa apenas ensaiar o argumento para a existência de Deus. Com o argumento em mente, é impossível a dúvida sobre sua percepção clara e distinta, e, portanto, sobre sua conclusão. Somente quando nós já não prestamos atenção a ela, é possível tal dúvida. Lembrando-nos de que temos esse argumento, pronto para ensaiar quando necessário, podemos então confiantemente aceitar algo mais do que percebemos clara e distintamente como verdadeiro, quando apenas nos lembramos de tê-lo percebido como verdadeiro.

Em segundo lugar, o que há com o cogito? Se ele depende do conhecimento da existência de Deus, então o que o dota de seu papel aparentemente único nas Meditações? Por que todas as percepções claras 
e distintas da verdade, cujo assentimento impõem, não iriam derrotar o demônio-hipótese? A resposta é aquela, talvez óbvia, que o demôniohipótese derrota a si mesmo e, por conseguinte, não proporciona uma base "razoável" para a dúvida. ${ }^{24}$ Para expressar a dúvida putativa, Descartes de fato tem que "virar [sua] vontade na direção completamente oposta", contra a razoabilidade e a verdade, "ao fingir que [suas crenças] são completamente falsas e imaginárias." Esse fingimento é exatamente o que o cético pirrônico faz, como Descartes efetivamente admite na frase seguinte, com um apelo à epokhé enquanto um estado psicológico: "Eu farei isso até que o peso de uma opinião preconcebida seja contrabalançado e a influência deturpadora do hábito não impeça mais meu juízo de perceber as coisas corretamente." 25 A tentativa de duvidar com base no demônio fracassa de imediato, é claro, e com isso proporciona ao mesmo tempo um modelo para a certeza de tudo o mais, e uma explicação sobre por que a percepção clara e distinta da verdade não pode ser objeto de dúvida enquanto é a clara e distinta percepção da verdade. Para mim, duvidar de que eu exista é uma contradição pragmática, exatamente como é para mim dizer que dois e três são cinco, mas eu não acredito nisso. $\mathrm{O}$ cético pirrônico ou é desesperadamente ingênuo (nunca tendo uma clara e distinta percepção da verdade), ou é um mentiroso sobre as percepções que teve, e é digno apenas de desprezo em ambos os casos.

Finalmente, eu tentei separar Descartes da interpretação-padrão segundo a qual ele cai no ceticismo, malgré lui. Contudo, ironicamente, resulta de meu artigo que Descartes é mesmo um cético. Seu ceticismo não é, todavia, pirrônico, mas acadêmico; não é abraçado como que por acaso, mas deliberadamente como sua metodologia; e não é uma falha, mas o supremo feito heróico da filosofia.

\footnotetext{
${ }^{24}$ AT VII, 22, linha 11.; CSM II, 15, linha 12.

${ }^{25}$ AT VII, 22; CSM II, 15.18
} 


\section{REFERÊNCIAS}

CHARRON, Pierre. Oeuvres. Paris: Slatkine, 1635; Geneva: Slatkine, 1970.

CICERO. Academica. Tradução de H. Rackham. Loeb. Cambridge: Harvard University Press, 1979.

DESCARTES, René. The Philosophical Writings. Tradução de J. Cottingham, R. Stoothoff, D. Murdoch. Cambridge: University Press, 1985.

DIOGENES, Laertius. Lives of Eminent Philosophers. Tradução de R.D. Hicks. Cambridge: Harvard University Press, 1979.

EUSEBIUS. Preparation for the Gospel. Tradução de E. H. Gifford. Grand Rapids: Baker Book, 1981.

LARMORE, Charles. Scepticism. In: GARBER, D.; AYERS, M. (Org.) The Cambridge History of Seventeenth-Century Philosophy. Cambridge: Cambridge University Press, 1998.

LENNON, Thomas M. The Plain Truth: Descartes, Huet, and Skepticism. Leiden: Brill, 2008.

LONG, A. A.; SEDLEY, D. N. The Helenisic Philosophers. Cambridge: Cambridge University Press, 1987. v. 2.

MAIA NETO, José R. Charron.s Epoche and Descartes.s cogito: The sceptical basis of Descartes.s refutation of skepticism. In: PAGANINI, G. (Org.) The Return of Sceptisicm. Dordrecht: Kluwer, 2003. p. 81113.

Foucher.s Academic Cartesianism. In: LENNON T. M. (Ed.) Cartesian Views: Papers presented to Richard A. Watson. Leiden: Brill, 2003. p. 71-95.

MATES, Benson. The Skeptic Way. New York: Oxford University Press, 1996. 
MONTAIGNE. The Complete Essays. Tradução de SCREECH M. A. (Ed.) London: Penguin, 1991.

Oeuvres completes. Paris: Editiond du Seuil, 1967.

PAGANINI, Gianni. Resenha de Lennon. Notre Dame Philosophical Reviews, on-line.

Skepsis: Le débat des modernes sur le scepticisme. Paris : J. Vrin, 2008.

SEXTUS, Empiricus. Outlines of Pyrrhonism. Tradução de BURY R. G. Loeb. Cambridge: Harvard University Press, 1933.

Selections, trans. Stanford Etheridge. Indianapolis: Hackett, 1985. Outlines of Skepticism. Tradução de ANNAS J.; BARNES J. Cambridge: University Press, 2000.

STANLEY, Thomas. The History of Philosophy. London, 3. ed., 1701.

Data de registro: $18 / 07 / 2011$

Data de aceite: $24 / 08 / 2011$ 
